\title{
Influence of the Barrie de la Maza dock on the circulation pattern of the Ría of A Coruña (NW-Spain)*
}

\author{
MONCHO GÓMEZ-GESTEIRA, MAITE DECASTRO ${ }^{1}$, RICARDO PREGO² \\ and FLAVIO MARTINS ${ }^{3}$ \\ ${ }^{1}$ Physical Oceanography Group. Faculty of Science. University of Vigo, 32004 Ourense, Spain. E-mail: \\ mggesteira@uvigo.es \\ ${ }_{2}^{2}$ Marine Biogeochemistry Research Group. Instituto de Investigaciones Marinas, CSIC, Vigo, Spain. \\ ${ }^{3}$ University of Algarve, Portugal.
}

\begin{abstract}
SUMMARY: A 3D hydrodynamical model is applied to the ria of A Coruña to analyze the evolution of the circulation pattern in the ria after the building of a breakwater (Barrie de la Maza dock) in the sixties. This circulation pattern has changed greatly. On the one hand, the circulation, which was almost parallel to the shore line under the original conditions, now shows a gyre near the end of the dock. On the other hand, a considerable increase (about 30\%) in the velocities near the end of the breakwater and in the main channel of the estuary has been observed after the building of the dock. A stronger bottom shear stress has been generated in the estuary areas where the velocity increased. The bottom shear stress increase was particularly great (over 100\%) near the end of the dock. This increase in the shear stress produced bottom erosion and matter resuspension, and consequently major changes in the bathymetry. In addition, in situ sedimentary measurements carried out by Lopez-Jamar (1996) corroborate the bottom erosion in the main chanel of the estuary and at the end of the dock produced by the velocity increase generated by the building of the breakwater.
\end{abstract}

Key words: Breakwater influence, Galician Rias, circulation pattern, bathymetry, shear stress.

RESUMEN: INFluencia del dique de BarRie de la MaZa sobre el patrón de CiRCUlación de la Ría de A CoRuña. Se ha aplicado un modelo hidrodinámico 3D a la Ría de A Coruña para el estudio de los cambios en el patrón de circulación de la ría tras la construcción del dique de Barrie de la Maza en los años sesenta. La circulación, la cual era casi paralela a la línea de costa bajo las condiciones originales, muestra en la actualidad un giro en las proximidades del extremo del dique. Además, puede observarse un considerable aumento (cercano al 30\%) en las velocidades medidas en el canal principal cerca del extremo del dique, con el consiguiente aumento en el arrastre cerca del fondo. Este arrastre es especialmente importante cerca del extremo del dique, donde se observa un aumento próximo al 100\%. Este aumento en el arrastre es responsable de importantes cambios en la batimetría de la zona. Medidas de campo realizadas por Lopez-Jamar (1996) corroboran la existencia de erosión en el canal principal del estuario cerca del extremo del dique.

Palabras clave: dique, rías gallegas, pautas de circulación, batimetría, arrastre.

\section{INTRODUCTION}

The Galician coast, located NW Spain, is very irregular in shape, with a great number of coastal

\footnotetext{
*Received October 23, 2001. Accepted June 26, 2002.
}

embayments called Rias. According to their geological origin, these rias are classified as Bajas, south of Cape Finisterre and Altas, north of Finisterre. The hydrodynamics of the Rias Bajas is driven by tides with a two-layered residual pattern (Otto, 1975; Fraga and Margalef, 1979; Prego and Fraga, 1992; 
Roson et al., 1997; Taboada et al., 1998; deCastro et al., 2000). This two-layered pattern is seasonally enhanced by coastal upwelling (Blanton et al., 1987; McClain et al., 1986; Tilstone et al., 1994). The hydrodynamics of the Rias Altas has received considerably less attention. In particular, only one of these rias, the Ria of A Coruña, has been studied in some detail. Cabanas et al. (1987) found the presence of a two-layered residual pattern in the innermost part of the ria. Varela et al. (1994) stated that the Ria of A Coruña is hydrologically a bay and Prego and Varela (1998) carried out a complete study of the hydrography of the Artabro Gulf (a 46$\mathrm{km}$ long arch including the rias of Coruña, Betanzos, Ares and Ferrol). Finally, the circulation pattern of the ria of A Coruña has been studied by means of a 2D hydrodynamic model (Montero et al., 1997; Gómez-Gesteira et al., 1999).

The aim of this paper is to decribe how the building of the Barrie de la Maza dock in the Ria of A Coruña induced major changes in the circulation pattern of the estuary and, in addition, how the new circulation pattern gives rise to further changes in the bathymetry of the area.

\section{AREA UNDER STUDY}

As mentioned above, the Ria of A Coruña is located in the Artabro Gulf (Fig. 1a). This ria has received much more attention than the remaining Rias Altas, mainly due to the great anthropogenic impact. On the one hand, the biggest city in the surroundings, the city of A Coruña, is located in this ria. The increasing population, now about 300,000 inhabitants, made it necessary to build a dam in the Mero River in 1976. On the other hand, the presence of the harbour required the building of a breakwater (Barrie de la Maza dock) in 1965 to provide protection to the harbour. It is quite likely that these changes both in the morphology of the estuary and in the freshwater discharge have given rise to significant changes in the circulation pattern.

The Ria of A Coruña (Fig. 1b) has a North-South orientation, with a length of about $5 \mathrm{~km}$. The ria communicates with the coastal shelf by a $3 \mathrm{~km}$ wide and $25 \mathrm{~m}$ deep mouth located in the northern part of the estuary. The previously described dock is about 1.2 $\mathrm{km}$ long, which is comparable to the estuary dimension. According to data from the Confederacion Hidrografica del Norte de España, the average discharge of the Mero River was $8.3 \pm 2.5 \mathrm{~m}^{3} \mathrm{~s}^{-1}$ (Vergara and Prego, 1997) over the period 1940-1987. As mentioned above, a dam was built in the river Mero, in such a way that seasonal changes in water discharge are not so marked. For example, the maximum and minimum discharges were $18 \mathrm{~m}^{3} \mathrm{~s}^{-1}$ and $1 \mathrm{~m}^{3} \mathrm{~s}^{-1}$ before the building of the dam and $9 \mathrm{~m}^{3} \mathrm{~s}^{-1}$ and $2 \mathrm{~m}^{3} \mathrm{~s}^{-1}$ afterwards. Nevertheless, this will not be considered in the present study, since we will consider the situation just after the building of the breakwater. The main tidal component is the M2-semidiurnal component modulated by $\mathrm{S} 2, \mathrm{~N} 2$ and $\mathrm{K} 2$ over the neap-spring cycle. Tidal range is $3.2 \mathrm{~m}$ at spring tides and $1.6 \mathrm{~m}$ at neap
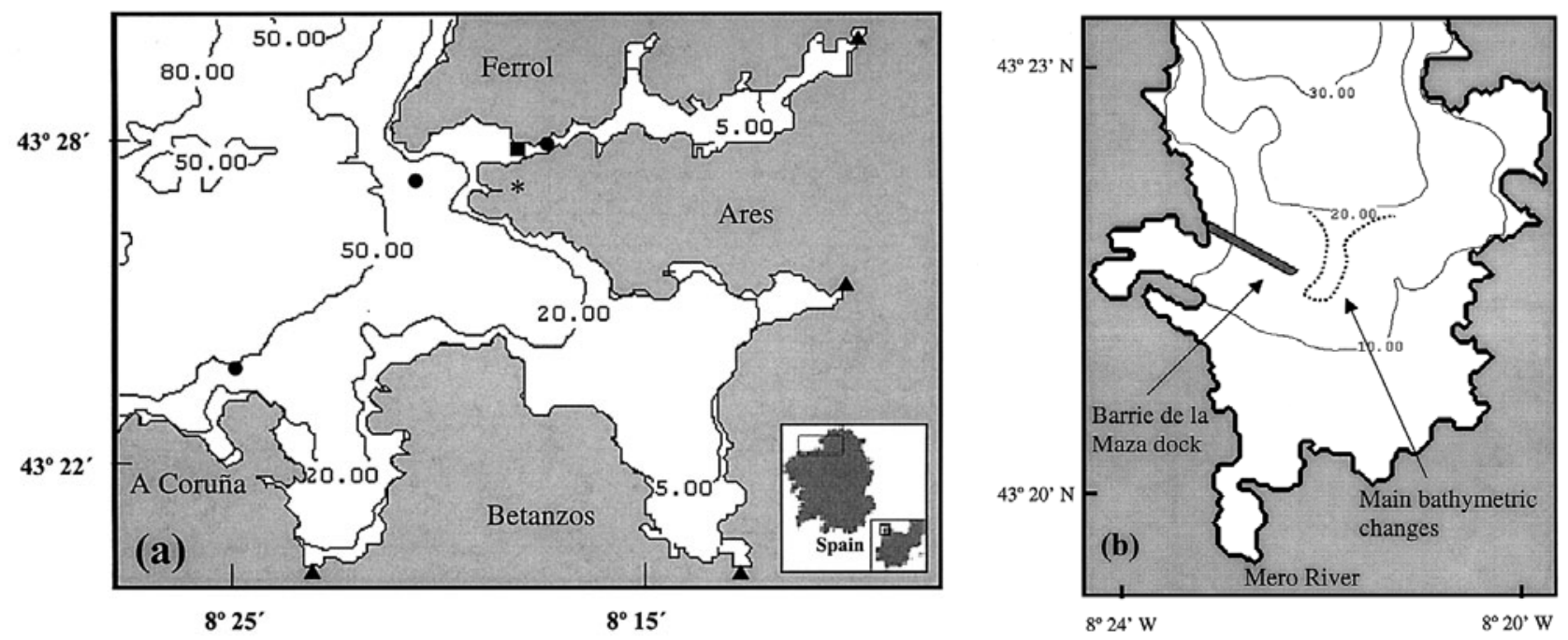

FIG. 1. - (a) Bathymetry of the Artabro Gulf at present. The square shows the position of the current meter, the circles the tidal gages, the triangles the position of the rivers and the asterisk the meteorological station. (b) Bathymetry of A Coruña before the building of the Barrie de la Maza dock. The dock is marked with a color darker than the one corresponding to the land. The dashed line represents the $20 \mathrm{~m}$ deep bathymetric line at present. 
tides, this estuary being mesotidal at spring tides and microtidal at neap tides. Figure $1 \mathrm{~b}$ shows the bathymetry of the Ria of A Coruña just after the building of the breakwater. Shaded areas mark the main changes of the bathymetry after that.

As for the bottom composition, there are marked differences in the average size of the sediment. López-Jamar (1996) showed that the size of sand ranges from about $100 \mu \mathrm{m}$ in the inner part of the estuary to almost $1000 \mu \mathrm{m}$ near the breakwater.

\section{THE MODEL}

The 3D hydrodynamic model (MOHID) with generic vertical coordinate (Martins et al., 1998; Martins, 1999; Montero, 1999) was developed by the MARETEC group of the Instituto Superior Tecnico of Lisbon. The model solves the 3D incompressible primitive equations in Cartesian form assuming hydrostatic equilibrium and Boussinesq approximation. The mass and momentum balance equations are:

$$
\begin{gathered}
\frac{\partial u}{\partial t}+\frac{\partial v}{\partial y}+\frac{\partial w}{\partial z}=0 \\
\frac{\partial u}{\partial t}+\frac{\partial(u u)}{\partial x}+\frac{\partial(v u)}{\partial y}+\frac{\partial(w u)}{\partial z}=f v \\
-g \frac{\rho_{\eta}}{\rho_{0}} \frac{\partial \eta}{\partial x}-\frac{1}{\rho_{0}} \frac{\partial p_{s}}{\partial x}-\frac{g}{\rho_{0}} \int_{z}^{\eta} \frac{\partial \rho^{\prime}}{\partial x} d z \\
+\frac{\partial}{\partial x}\left(A_{h} \frac{\partial u}{\partial t}\right)+\frac{\partial}{\partial y}\left(A_{h} \frac{\partial u}{\partial y}\right)+\frac{\partial}{\partial z}\left(A_{v} \frac{\partial u}{\partial z}\right) \\
\frac{\partial v}{\partial t}+\frac{\partial(u v)}{\partial x}+\frac{\partial(v v)}{\partial y}+\frac{\partial(w v)}{\partial z}=-f u \\
-g \frac{\rho_{\eta}}{\rho_{0}} \frac{\partial \eta}{\partial y}-\frac{1}{\rho_{0}} \frac{\partial p_{s}}{\partial y}-\frac{g}{\rho_{0}} \int_{z}^{\eta} \frac{\partial \rho^{\prime}}{\partial y} d z \\
+\frac{\partial}{\partial x}\left(A_{h} \frac{\partial v}{\partial x}\right)+\frac{\partial}{\partial y}\left(A_{h} \frac{\partial v}{\partial y}\right)+\frac{\partial}{\partial z}\left(A_{v} \frac{\partial v}{\partial z}\right) \\
\frac{\partial p}{\partial z}=-\rho g
\end{gathered}
$$

where $u, v$ and $w$ are the components of the velocity vector in the $x, y$ and $z$ directions respectively, $\eta$ is the free surface elevation, $f$ the Coriolis parameter, $A_{h}$ and $A_{v}$ the turbulent viscosity in horizontal and vertical directions and $\mathrm{p}_{\mathrm{s}}$ the atmospheric pressure. $\rho$ is the specific mass and $\rho$ ' the specific mass anom- aly $\left(\rho=\rho_{0}+\rho^{\prime}\right)$. The specific mass is calculated as a function of salinity and temperature by the constitutive law (Leendertse and Liu, 1978):

$$
\begin{gathered}
\rho=\left(5890+38 T-0.375 T^{2}+3 S\right) / \\
\left(\left(1779.5+11.25 T-0.074 T^{2}\right)-(3.8+0.01 T) S+\right. \\
\left.+0.698\left(5890+38 T-0.375 T^{2}+3 S\right)\right)
\end{gathered}
$$

Salinity and temperature values are provided by a transport equation:

$$
\begin{gathered}
\frac{\partial P}{\partial t}+\frac{\partial(u P)}{\partial x}+\frac{\partial(v P)}{\partial y}+\frac{\partial(w P)}{\partial z}= \\
=\frac{\partial}{\partial x}\left(k_{h} \frac{\partial P}{\partial x}\right)+\frac{\partial}{\partial y}\left(k_{h} \frac{\partial P}{\partial y}\right)+\frac{\partial}{\partial z}\left(k_{v} \frac{\partial P}{\partial z}\right)+S_{S T}
\end{gathered}
$$

where $P$ stands for $S$ or $T$ and $S_{S T}$ is a source-sink term. $k_{h}$ and $k_{v}$ are the horizontal and vertical diffusivities respectively.

\section{Finite volume discretization}

Though a complete description of the MOHID can be seen in Martins et al. (1998), we will describe here some of the main features of the model. The previous equations are solved by a finite volume method. In this approach the equations are solved in the real space integrated over each cell, which can have any shape since in integral form only the fluxes between adjacent cells are calculated. Thus, a complete separation between the physical variables and the geometry is accomplished (Vinokur, 1989).

In this particular application the vertices of the cells have been considered to posses only one degree of freedom: they can only vary along the vertical direction (see Fig. 2). The three coordinates of the velocity are staggered in an Arakawa-C manner.

The model uses a semi-implicit ADI algorithm with two time levels per iteration. A 4-equations S21 scheme (Abbott et al., 1973) is considered in the present application. The time marching procedure for this scheme can be described by:

$$
\begin{gathered}
\eta^{t+1 / 2}\left(u^{t+1}, u^{t}, v^{t+1 / 2}, v^{t-1 / 2}\right) \rightarrow u^{t+1} \rightarrow w_{r}^{* t+1 / 2} \rightarrow \cdots \\
\quad \stackrel{\text { geometry update }}{\rightarrow} w_{r}^{t+1 / 2} \rightarrow S^{t+1 / 2}, T^{t+1 / 2} \rightarrow \cdots \\
\cdots \rightarrow \eta^{t+1}\left(u^{t+1}, u^{t}, v^{t+3 / 2}, v^{t+1 / 2}\right) \rightarrow v^{t+3 / 2} \rightarrow \cdots \\
\cdots \rightarrow w_{r}^{* t+1} \stackrel{\text { geometry update }}{\rightarrow} w_{r}^{t+1} \rightarrow S^{t+1}, T^{t+1} \rightarrow \cdots
\end{gathered}
$$




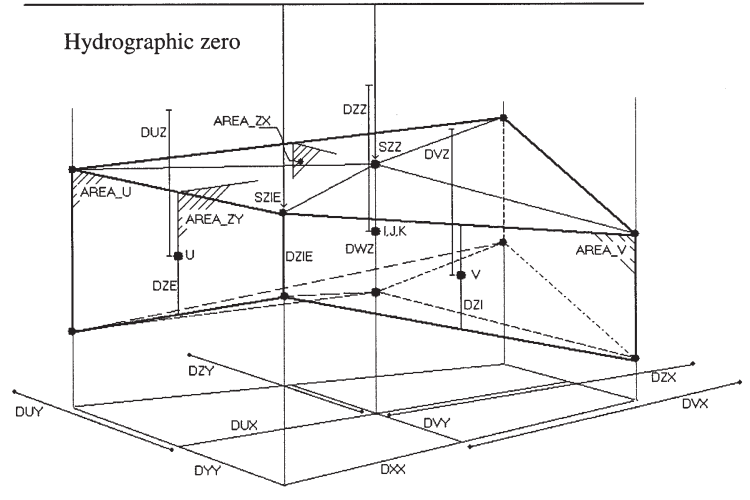

FIG. 2. - Cell geometry and nomenclature.

In the finite volume method the natural choice of dependent variables are the water fluxes instead of the velocities. Thus, $\mathrm{U}_{f l u x}, \mathrm{~V}_{f l u x}$ and $\mathrm{W}_{f l u x}$, will be used in the discretised form of Equations 1-4, 6. Using this approach, the discretised equations will be obtained by integration of the primitive differential equations.

\section{Calibration}

The model was calibrated using the bathymetry of the Artabro Gulf at present (Fig. 1a) after a spinup of 5 days. A 3D barotropic calculation was used to simulate the current pattern because, as we mentioned in the last section, tide is the main force in the area. In addition, pervious papers (Varela et al., 1994;. Gómez- Gesteira et al., 1999) show the well mixed nature of the estuary. Thus, baroclinic forcing can be initially neglected. Nevertheless, the calculations cannot be considered two-dimensional since there are major changes in the velocity profile due to wind forcing and bottom friction. Three tidal gauges placed at $43^{\circ} 24.203^{\prime} \mathrm{N}, 8^{\circ} 23.312^{\prime} \mathrm{W}$; $43^{\circ} 27.665^{\prime} \mathrm{N}$, $8^{\circ} 17.201^{\prime} \mathrm{W}$ and $43^{\circ} 27.531^{\prime} \mathrm{N}, 8^{\circ} 20.621^{\prime} \mathrm{W}$ and a Doppler Current meter placed at $43^{\circ} 27.634^{\prime} \mathrm{N}$, $8^{\circ} 17.223^{\prime} \mathrm{W}$ were considered to calibrate the model (see Fig. 1a). Real wind data measured at Monte Faro $\left(43^{\circ} 27^{\prime} \mathrm{N}, 8^{\circ} 17^{\prime} \mathrm{W}\right)$ were also used to calibrate the model (Fig. 3a-b). The parameters used in these calculations are summarised in Table 1.

Figure 4a-c shows a perfect agreement between the calculated and measured sea elevation at the three tidal gauges. As observed in field measurements, numerical calculations show that the sea elevation was in phase at the three considered positions. In addition, Figure 5 shows a good agreement between the axial and transverse component of the calculated and measured velocity at $43^{\circ} 28.455^{\prime} \mathrm{N}$, $8^{\circ} 17.223^{\prime} \mathrm{W}$. This agreement is observed both at bottom layers (Fig. 5a-b) and at surface layers (Fig. 5cd). Note that at the chosen position the axial component of water velocity is much bigger than the transverse one due to the particular features of the estuary at that point.
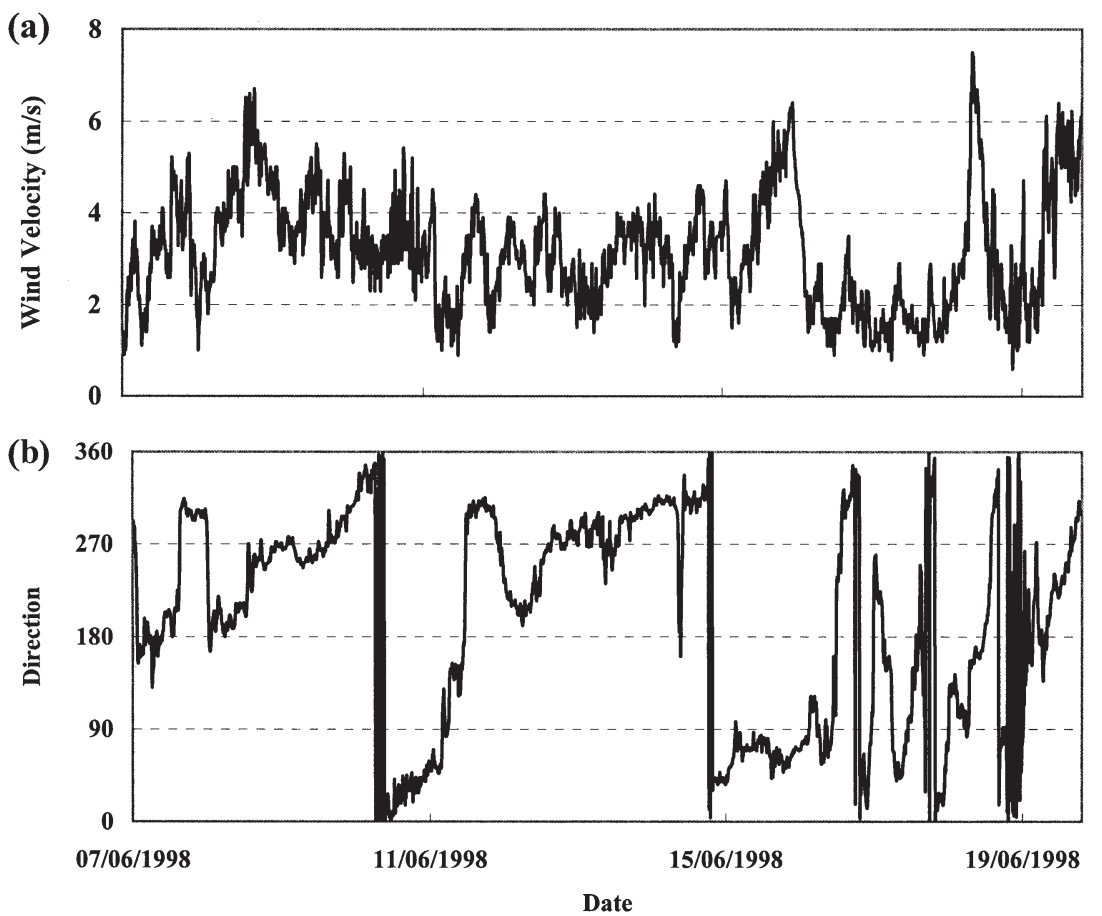

FIG. 3. - Wind velocity at the meteorological station placed at Monte Faro $\left(43^{\circ} 27^{\prime} \mathrm{N}, 8^{\circ} 17^{\prime} \mathrm{W}\right)$. (a) Wind intensity; (b) Wind direction. 
TABLE 1. - Parameters used in the numerical calculations.

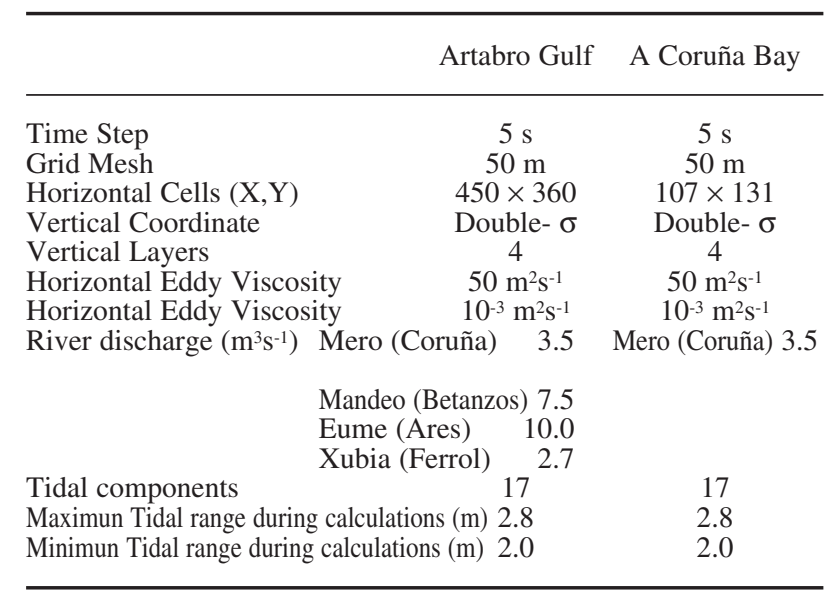

\section{RESULTS AND DISCUSSION}

Barotropic calculations were used to show the main changes in the circulation pattern due to the presence of the breakwater. A typical summer situation with a low river discharge was run with the bathymetry shown in Fig. 1b, with and without the breakwater. In both cases a 5 day spin-up was considered to achieve a stationary situation. As we mentioned above, the parameters used in these calculations are summarised in Table 1 . This summer situation is similar to the one observed in winter in preliminary studies about residence time in the ria of A Coruña (Gómez- Gesteira et al., 2001).

Figure 6(a-b) shows the circulation pattern corresponding to the surface layer at flood tide with

(a)

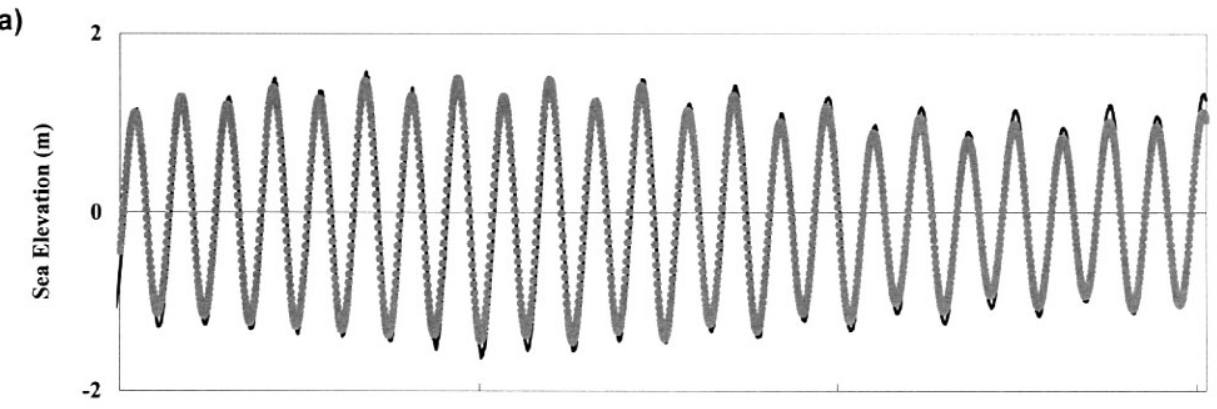

(b)

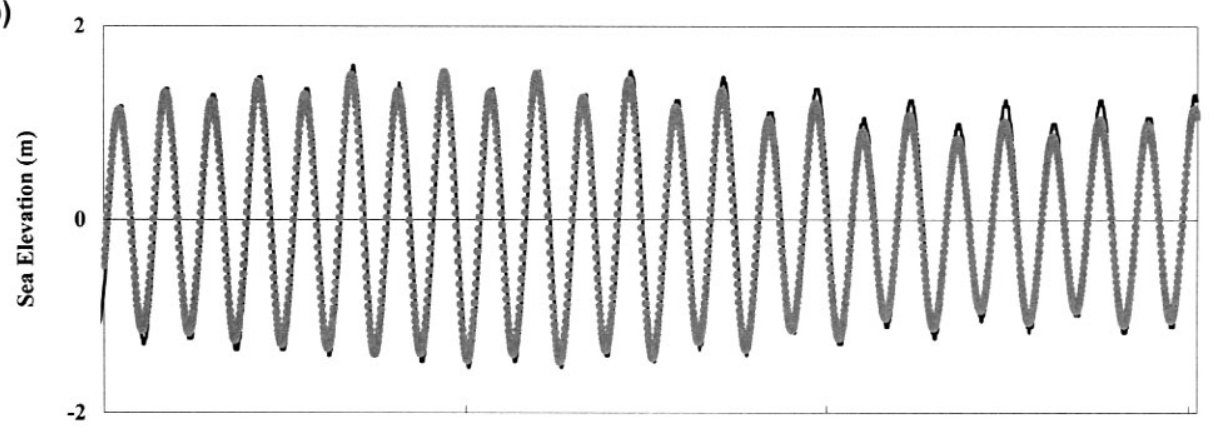

(c)

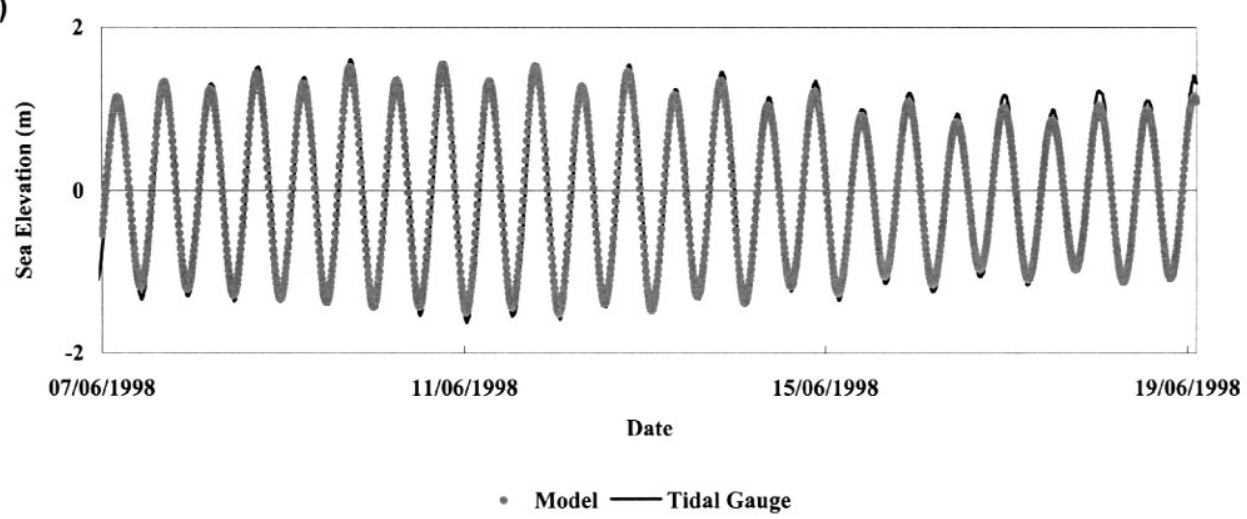

FIG. 4. - Calibration of the numerical model. The sea elevation measured at points (a) $43^{\circ} 24.203^{\prime} \mathrm{N}, 8^{\circ} 23.312^{\prime} \mathrm{W}$; (b) $43^{\circ} 27.665^{\prime} \mathrm{N}$, $8^{\circ} 17.201^{\prime} \mathrm{W}$ and (c) $43^{\circ} 27.531^{\prime} \mathrm{N}, 8^{\circ} 20.621^{\prime} \mathrm{W}$ (see Figure 1a) is compared to the sea elevation provided by the numerical model at the same points. 

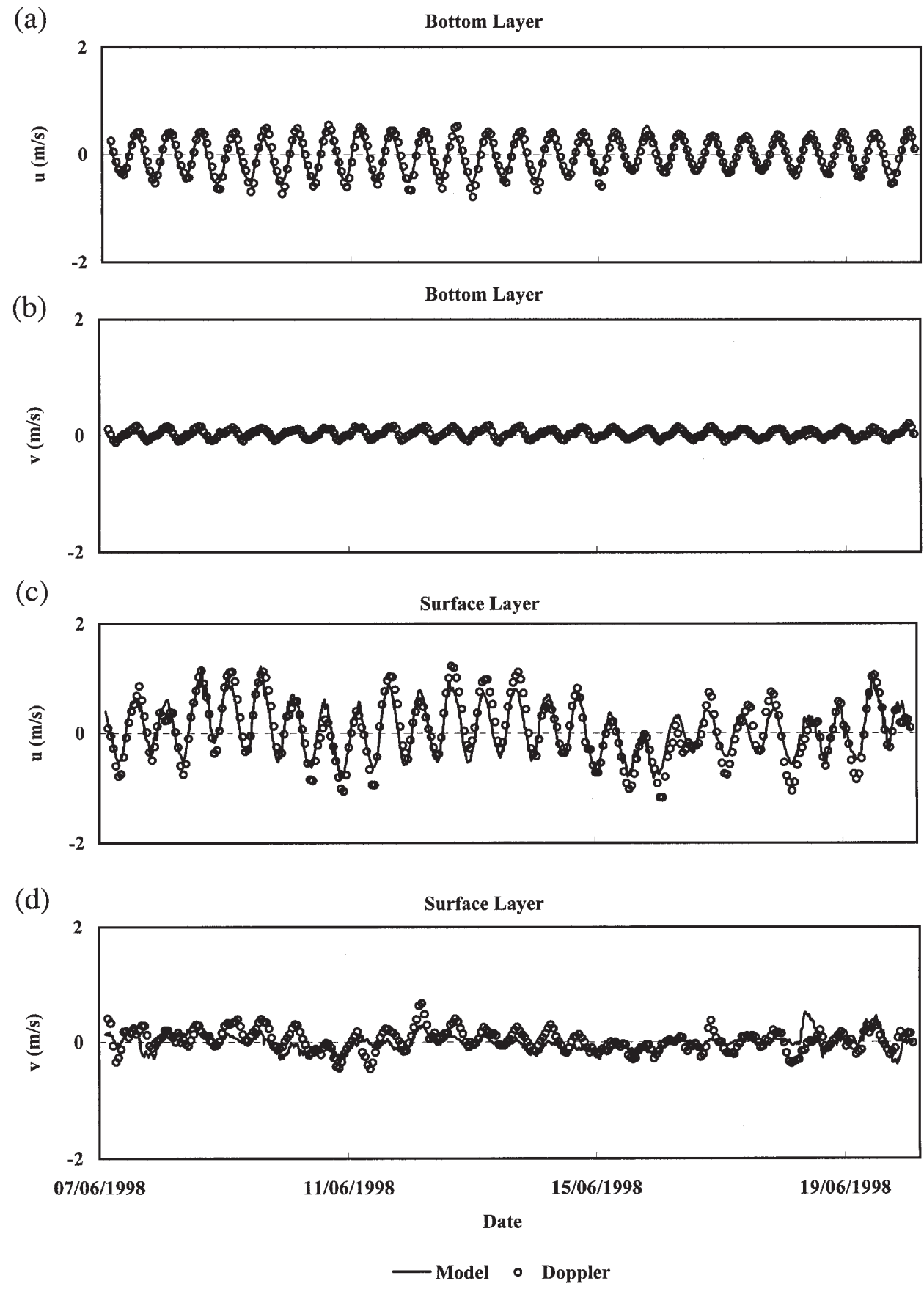

FIG. 5. - Calibration of the numerical model. The axial and transversal current velocities measured at the point $43^{\circ} 28.455^{\prime} \mathrm{N}, 8^{\circ} 17.223^{\prime} \mathrm{W}$ (about $22 \mathrm{~m}$ deep) are compared with the velocities provided by the numerical model. (a) Axial and (b) transversal components of bottom velocity (about $5.5 \mathrm{~m}$ from the bottom); (c) Axial and (d) transversal components of surface velocity (about $3 \mathrm{~m}$ from the surface).

and without the breakwater. The pattern corresponding to ebb tide with and without the breakwater is shown in Figure 6 (c-d). The pictures obtained before the building of the breakwater (Fig. 6a and 6c) show a quasi-symmetric pattern, with some gyres close to the lateral embayments. In the rest of the estuary the velocities are quite similar except near the river mouth. This symmetry appears bro- ken in the pictures obtained after the building of the breakwater (Fig. 6b and 6d). In this case, a considerable clock-wise gyre (counter clock-wise gyre) is observed near the end of the breakwater during flood (ebb) tide. In addition, due to the decrease in the water section the current velocities in this area are larger than in the corresponding area before the building of the breakwater. In particular, the veloc- 
ities increase from $0.12 \mathrm{~m} \mathrm{~s}^{-1}$ to $0.20 \mathrm{~m} \mathrm{~s}^{-1}$ during flood tide and from $0.10 \mathrm{~m} \mathrm{~s}^{-1}$ to $0.15 \mathrm{~m} \mathrm{~s}^{-1}$ during ebb tide. This behaviour observed at surface layers is qualitatively similar to that observed at bottom layers, although near the bottom the velocities are smaller due to bottom friction.
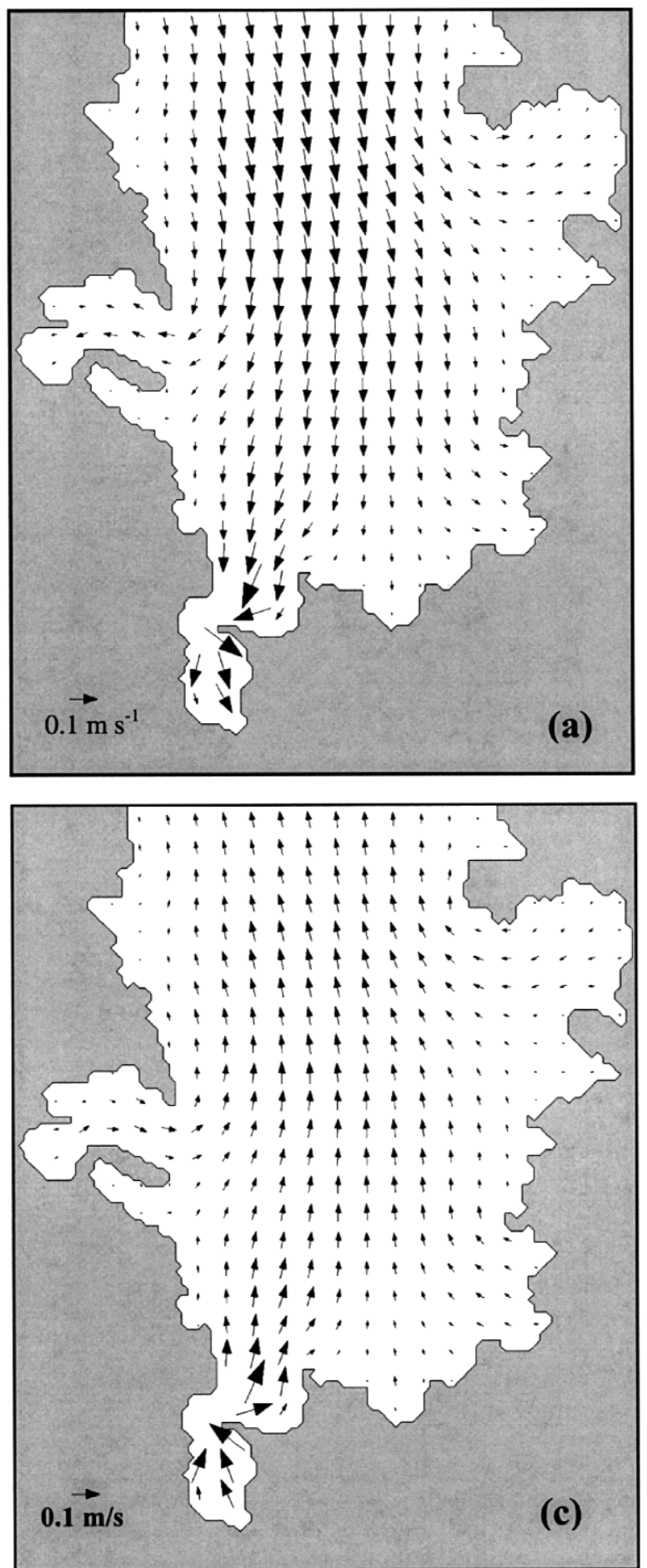

To quantify the effect of these differences on the erosion-deposition processes the bottom shear stress $\left(\tau_{\mathrm{b}}\right)$ was calculated under both situations. It is a well known fact that resuspension occurs when $\tau_{\mathrm{b}}$ exceeds a certain threshold $\tau_{c}$. Therefore, the rate of bed load transport can be determined using expres-
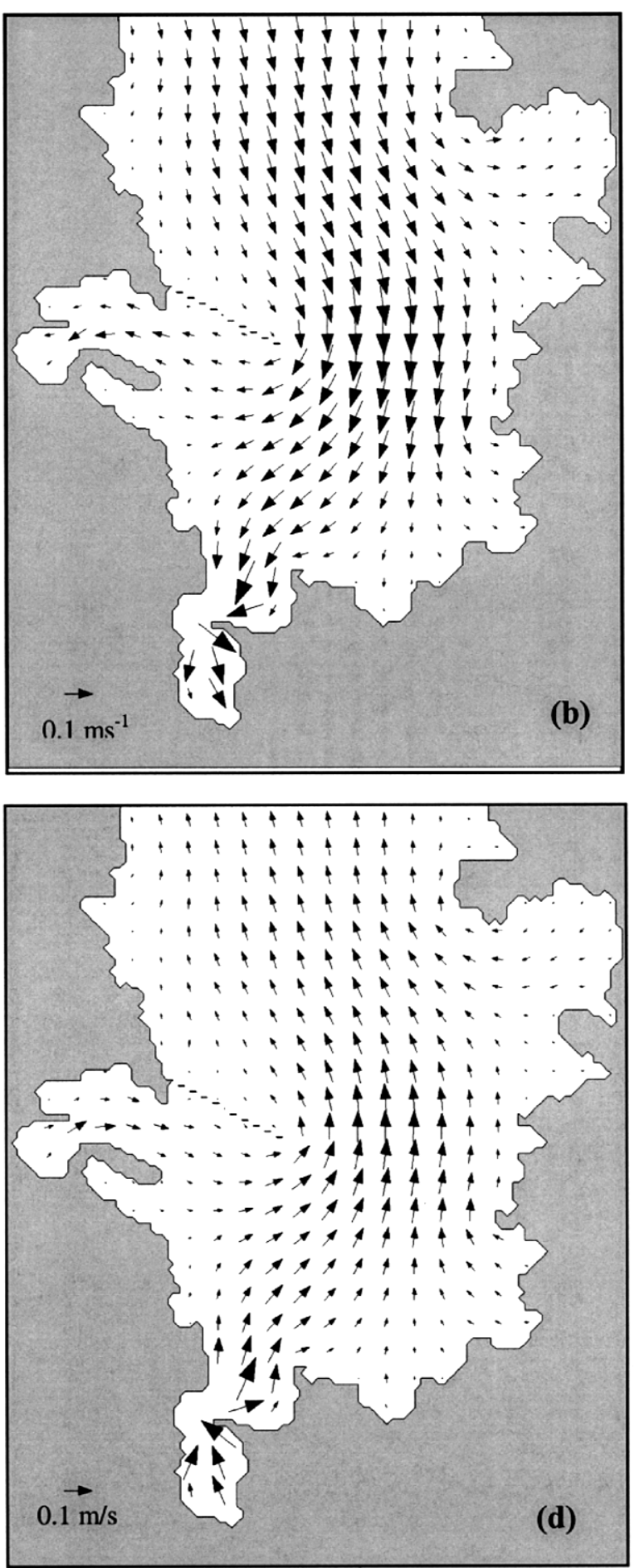

FIG. 6. - Barotropic circulation pattern corresponding to the surface layer at flood and ebb tide. (a) Flood tide before the building of the Barrie de la Maza dock; (b) Flood tide after the building of the dock; (c) Ebb tide before the building of the Barrie de la Maza dock; (d) Ebb tide after the building of the dock . 
sions similar to the relation proposed by Duboys in 1879 (Cardoso, 1984), where the transport is proportional to $\tau_{\mathrm{b}-} \tau_{\mathrm{c}}$. The expression proposed by Duboys has been improved during the last few decades. However, expressions applied today, such as the one proposed by Meyer-Peter and Muller (Koutitas, 1988) still show that the transport is zero if the bottom shear stress $\tau_{b}$ is lower than the threshold shear stress $\tau_{c}$, although the relation between the transport and $\left(\tau_{b}-\tau_{c}\right)$ is not linear. The threshold shear stress $\tau_{c}$ can be determined using sediment properties such as the density of the material and the radius of the particles. However, the relationship is not straightforward. This critical shear stress can be computed from the Shields diagram (Koutitas, 1988), and can also be experimentally determined (Mei et al., 1997; Chao, 1998).

The bottom shear stress was calculated by means of the barotropic velocities calculated using both bathymetries, before and after the building of the breakwater. This bottom shear stress is determined from:

$$
\tau=\rho_{0}\left(\frac{k}{\log \left(\frac{z}{z_{0}}\right)}\right)^{2}\left(u^{2}+v^{2}\right)
$$

where $\mathrm{k}$ is the von-Karman constant, $\mathrm{z}_{0}$ is the effective roughness height, $\rho_{0}$ is the density, $\mathrm{z}$ is the bottom layer height and $\mathrm{u}$ and $\mathrm{v}$ are the horizontal components of the velocity. According to LopezJamar et al. (1986) and Lopez-Jamar (1996), the median particle size in most of the estuary is 100$200 \mu \mathrm{m}$. These authors did not describe the existence of ripples or dunes, so the effective bed roughness mainly consists of grain roughness generated by skin friction forces. Following (van Rijn, 1993) the grain roughness, $\mathrm{z}_{0}$, can be estimated in the range of 1 to $10 \mathrm{~d}_{90}$ of the bed material for particles in the range of 100 to $5000 \mu \mathrm{m}$. For particles with a d90 of $300 \mu \mathrm{m}$, which are characteristic in the Ria of a Coruña, one can estimate $\mathrm{z}_{0}$ ranging from 300 to $3000 \mu \mathrm{m}$. A mean $z_{0}$ in this interval $(1600 \mu \mathrm{m})$ was considered in our calculations. Sensibility tests did not show significant changes for $\mathrm{z}_{0}$ ranging from 500 to $5000 \mu \mathrm{m}$.

Numerical simulations show important changes in bottom shear stress. Figure 7 was obtained by subtracting the bottom shear stress calculated with the old bathymetry from the bottom shear stress cal- culated with the new bathymetry. In fact, the percentage of difference between the two patterns was normalised using the expression:

$$
\tau_{i j}^{\text {diff }}=\frac{\left(\tau_{i j}^{\text {after }}-\tau_{i j}^{\text {before }}\right)}{\tau_{i j}^{\text {before }}} \times 100
$$

Thus, $\tau_{i j}^{d i f f}>0$ represents an increase in the bottom shear stress and $\tau_{i j}{ }^{d i f f}<0$ a decrease.

The most striking feature is the split of the estuary into two regions. While the bottom shear stress has decreased in the western area, mainly near the dock, it has considerably increased in the eastern area. In particular, the area near the breakwater end shows the highest increase in the bottom shear stress. The area with an increase of about 100\% coincides with the area where major changes in bathymetry have been observed. Though there is a region where the bottom shear stress has increased by more than $200 \%$, not changes in the bathymetry of the zone have been observed, due to the rocky nature of the bottom.

In summary, a hydrodynamical model has been applied in an area of considerable human influence, the Ria of A Coruña, in order to show the differences

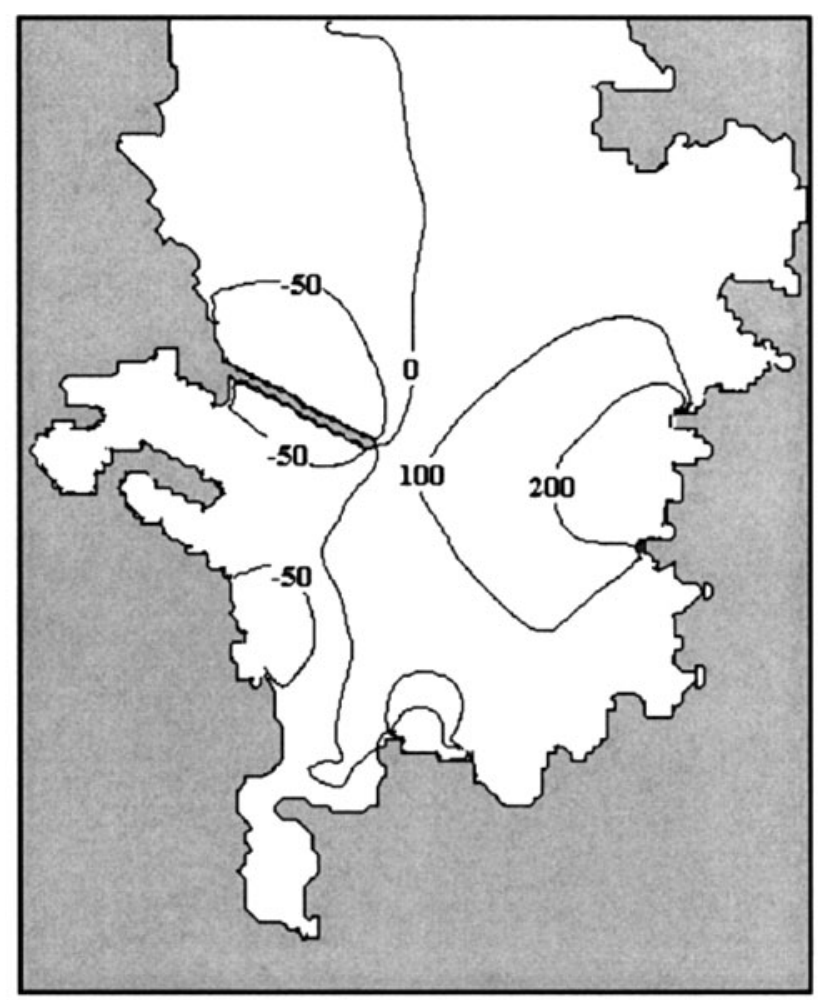

FIG. 7. - Difference between the bottom shear stress calculated using the bathymetry with and without the breakwater (see Eq. 9). The bottom shear stress has considerably increased in the eastern part of the estuary, mainly in the region close to the end of the breakwater. 
induced by the presence of the Barrie de la Maza dock. Only a particular summer case was considered in our calculations, since preliminary studies in the same area (Gómez-Gesteira at al., 2001) show a similar circulation pattern in winter. Thus, the depicted case can be considered to be representative of a general, non-seasonal situation, at least from the point of view of the stress exerted on the bottom. The circulation pattern before the building of the breakwater was parallel to the main axis of the Ria, varying smoothly in the direction perpendicular to this axis. The building of the breakwater broke this symmetric pattern and led to the appearance of a gyre near the end of the breakwater and a considerable increase (up to $30 \%$ ) in the velocity in this area. These changes in the circulation pattern can induce changes in the bathymetry of the area, which can be corroborated by two facts: (1) as mentioned above, recent sedimentological studies in the Ria of A Coruña (López-Jamar, 1996) show the appearance of coarse sand in the area of the main channel closest to the breakwater. The average size of the sediment grain in the main channel and in the outermost part of the Ria is about $100 \mu \mathrm{m}$. However, in the area of the main channel closest to the breakwater the average size of sand is close to $1000 \mu \mathrm{m}$. (2) The calculated bottom shear stress has decreased in the western part and increased in the eastern part. This increase is particularly great in the region near the end of the breakwater, coinciding with the area where the presence of coarse sand was observed. Though both facts seem to corroborate our hypothesis about the observed changes in bathymetry, both are qualitative arguments. A sediment transport model is being coupled to the hydrodynamic model to study the evolution of sediment from the building of the breakwater. To provide this quantitative evolution of the estuary, the model not only considers the effect of the currents generated by the new location of the dock, but also the role played by wind waves.

\section{ACKNOWLEDGEMENTS}

The numerical model was calibrated in the area under study using field data provided by the Instituto Español de Oceanografía (A Coruña) within the framework of the project Estudio Integral del Espacio Marítimo Terrestre de Galicia (Consellería de Pesca, Marisqueo e Aquicultura, Xunta de Galicia). This work was partially supported by the University of Vigo under project "Análisis y Modelado del transporte de metales y sustancias contaminantes en la Ría de Vigo". We would like to thank J.J. Taboada and P. Montero (Universidad de Santiago de Compostela) for helpful suggestions.

\section{REFERENCES}

Abbott, M.B. A. Damsgaardand and G.S. Rodenhius. - 1973. System 21, Jupiter, a design flow for two-dimensional nearly horizontal flows. J. Hyd. Res., 1: 1-28.

Blanton, J.O., K.R. Tenore, F. Castillejo, L.P. Atkinson, F.B. Schwing and A. Lavin. - 1987. The relationship of upwelling to mussel production in the rias on the western coast of Spain. $J$. Mar. Res., 45: 79-90.

Cabanas, J.M., M.T. Nunes, M.L. Iglesias, M.L. González and R. Carballo. - 1987. Oceanografía de la bahía de La Coruña. Bol. Inst. Esp. Oceanogr., 4: 21-28.

Cardoso, A.H. - 1984. Transporte sólido por arrastameto em escoamentos com superficie livre. ICT, Informacao Tecnica Hidraulica, 10, Lisboa.

Chao, S. - 1998. Hyperpicnal and buoyant plumes from a sedimentladen river. J. Geophys. Res., 103: 3067-3082.

DeCastro, M., M. Gomez-Gesteira, R. Prego, J.J. Taboada, P. Montero, P. Herbello and V. Perez-Villar. - 2000. Wind and tidal influence on water circulation in a Galician ria (NW Spain). Estuar. Coast. Shelf Sci., 51: 161-176.

Fraga, F. and R. Margalef. - 1979. Las Rias Gallegas. In: F. Fraga and R. Margalef (eds.), Estudio y explotación del mar en Galicia, pp. 101-122. Cursos y Congresos, University of Santiago, Santiago de Compostela.

Gómez-Gesteira, M., P. Montero, R. Prego, J.J. Taboada, R. Neves and V. Pérez-Villar. - 1999. A two-dimensional particle tracking model for pollution dispersion in A Coruña and Vigo Rias (NW, Spain). Oceanol. Acta, 22: 167-177.

Gómez-Gesteira, M., M. deCastro, J.J. Taboada, R. Prego, P. Montero, F. Martins and V. Pérez-Villar. 2001. Evolution of the circulation pattern in the Ria of A Coruña (NW Spain): Residence time in the harbor area. In: J. d'Elbée and P. Prouzet (eds.), Oceanographie du Golfe de Gascogne, pp. 256-261. Editions IFREMER, Brest.

Koutitas, C.G. - 1988. Mathematical Models in Coastal Engineering. Pentech Press, London.

Leendeertse, J.J. and S.K. Liu. - 1978. A three-dimensional turbulent energy model for non-homogeneus estuaries and coastal sea systems. In: J.C.J. Nihoul (ed.), Hydrodynamics of Estuaries and Fjords, pp. 387-405. Elsevier Publ. Co, Amsterdam.

López-Jamar, E., G. González and J. Mejuto. - 1986. Temporal changes of the community structure and biomass in two subtidal assemblages in La Coruña Bay, NW Spain. Hidrobiología, 142: $137-150$.

López-Jamar, E. - 1996. Consecuencias del vertido de crudo del Aegean Sea sobre la macrofauna bentónica submareal. In: Seguimiento de la contaminación producida por el accidente del buque Aegean Sea, pp. 67-75. Centro de publicaciones. Secretaría General Técnica. Ministerio de Medio Ambiente. Madrid.

Martins, F., R.J. Neves and P.C. Leitao. - 1998. A three-dimensional hydrodynamic model with generic vertical coordinate. In: Hydroinformatics'98. Vol. 2, pp. 1403-1410. Balkema, Rotterdam.

Martins, F. - 1999. Modelacao matemática tridimensional de escoamentos costeiros e estuarinos usando uma abordagem de coordenada vertical genérica. Ph.D. Thesis. Universidade Técnica de Lisboa.

McClain, C.R., S. Chao, L.P. Atkinson, J.O. Blanton and F. Castillejo. - 1986. Wind driven upwelling in the viciniy of Cape Finisterre, Spain. J. Geophys. Res., 91: 8470- 8486.

Mei, C.C., S. Fan and K. Jin. - 1997. Resuspension and transport of fine sediments by waves. J. Geophys. Res., 102: 15807-15822.

Montero, P., R. Prego, M. Gómez- Gesteira, R. Neves, J.J. Taboada and V. Pérez-Villar. - 1997 Aplicación de un modelo 2D al transporte de partículas en la bahía de la Coruña. In: Prego R. 
and J.M. Fernández (eds.), Actas del VIII Seminario Ibérico de Química Marina, pp. 131-136. Excma. Diputación de Pontevedra, Pontevedra.

Montero, P. - 1999 Estudio de la hidrodinámica de la Ría de Vigo mediante un modelo de volúmenes finitos. Ph.D. Thesis. Universidad de Santiago de Compostela.

Otto, L. - 1975. Oceanography of the Ria de Arosa (NW Spain). Konik, Meteor International Medelingen en Verlan: 96: 210.

Prego, R. and F. Fraga. - 1992. A simple model to calculate the residual flows in a Spanish Ria. Hydrographic consequences in the Ria of Vigo. Estuar. Coast. Shelf Sci., 34: 603-615.

Prego, R. and M. Varela. - 1998. Hydrography of the Artabro Gulf in summer: western coastal limit of Cantabrian seawater and wind-induced upwelling at Prior Cape. Oceanol. Acta, 2: 145156.

Rosón, G, X.A. Álvarez-Salgado and F.F. Pérez. - 1997 A non-stationary box model to determine residual fluxes in a partially mixed estuary, based on both termohaline properties: Application to the Ria of Arousa (NW Spain). Estuar. Coast. Shelf Sci., 44: 249-262.

Taboada J.J., R. Prego, M. Ruiz-Villarreal, M. Gómez-Gesteira, P.
Montero, A.P. Santos and V. Pérez-Villar. - 1998. Evaluation of the seasonal variations in the residual pattern of the Ria of Vigo (NW Spain) by means of a 3D baroclinic model. Estuar. Coast. Shelf Sci., 47: 661-670.

Tilstone, G.H., F.G. Figueras and F. Fraga. - 1994. Upwellingdownwelling sequences in the generation of red tides in a coastal upwelling system. Mar. Ecol. Prog. Ser., 112: 241-253.

Van Rijn, L.C. - 1993. Principles of Sediment Transport in Rivers, Estuaries and Coastal Seas. Aqua Publications, Amsterdam.

Varela, M., R. Prego, M. Canle and J. Lorenzo. - 1994. The Ría de La Coruña is hydrologically a Ria?. Gaia, 9: 3-5.

Vergara, J. and R. Prego. - 1997. Estimación de los aportes fluviales de nitrato, fosfato y silicato hacia las Rias. In: R. Prego and J.M. Fernández (eds.), Actas del VIII Seminario Ibérico de Química Marina, pp. 33-40. Excma. Diputación de Pontevedra, Pontevedra.

Vinokur M. - 1989. An analysis of finite-difference and finite-volume formulations of conservation laws. J. Comput. Phys., 81: $1-52$.

Scient. ed.: A. Sánchez-Arcilla 